This is the peer-reviewed version of the following article:

Reed, Ashley. "Craft and Care: The Maker Movement, Catherine Blake, and the Digital Humanities." Essays in Romanticism, vol. 23, no. 1, 2016, pp. 23-38.

which has been published in final form at https://doi.org/10.3828/eir.2016.23.1.4. Copyright 2016 by Liverpool University Press.

\title{
Craft and Care: The Maker Movement, Catherine Blake, and the Digital Humanities
}

\section{Ashley Reed}

In March 2009 Gareth Branwyn, then Editorial Director of Maker Media, published an article in Make Magazine titled "William Blake: Patron Saint of Makers." In it he described in detail the illuminated printing process that Blake invented, extolling the difficult but artistically liberating process of drawing, etching, and printing original works of art using copper plate, the engraver's press, and "pristine white paper." Blake, Branwyn asserted, “didn't want to create work for you to passively consume; he wanted to create work that would inspire you to make something yourself?" Branwyn compared Blake's illuminated prints_-art and poetry appearing together on the same plate—to advances in desktop publishing in the 1980s: "William Blake was a zine publisher! William Blake was a multimedia artist!' Blake's famous declaration of artistic and intellectual independence- "I must create my own system or be enslaved by another man's"—-was really the "ultimate maker statement,"2 and Blake himself was the paradigmatic model of independent

I would like to thank Roger Whitson and Jon Saklofske for their kind invitation to join this cluster and for their thoughtful comments on my essay. I would also like to thank Alan Vardy, Michael Gamer, and EIR's anonymous reviewer for their suggestions, which were simultaneously challenging and collegial.

${ }^{1}$ Gareth Branwyn, "William Blake: Patron Saint of Makers," Make: DIY Projects, How-Tos, Electronics, Crafts and Ideas for Makers, March 10, 2009.

${ }^{2}$ Branwyn published another article on Blake in Make a year and a half later, on the artist's birthday. (Gareth Branwyn, "Maker Birthdays: William Blake," Make: DIY Projects, How-Tos, Electronics, Crafts and Ideas for Makers, November 20, 2010.) And a search for "William Blake" on the Make site returns 32 results_about 3 mentions per year since the magazine launched in 2005. In addition to his role 
artisanship and creative freedom. In this hagiographic account of Blake-as-Maker, the artist's wife and lifelong collaborator Catherine received a passing mention: the "lovely Catherine," Branwyn asserted, was "especially adept at printing, and in hand-coloring the printed pages."

Like the Maker movement, the scholarly field known as the digital humanities has also claimed William Blake as a central figure: some of the earliest digital humanities projects, including the William Blake Archive (www.blakearchive.org) and the Blake Digital Text Project (www.english.uga.edu/ nhilton/wblake/home1.html), used the emerging medium of the web to present Blake's work in new ways and to wider audiences. The digital humanities are "an artisan field.... [S]cholars don't just write about media objects—-they create those objects as a part of their academic work." ${ }^{3}$ Digital humanists, like proponents of the Maker movement, celebrate the process and product of creation, building online tools and experimenting with 3-D printers and single-board computers like the Arduino and Raspberry Pi. And at their best, they interrogate both process and product. Scholars advocating for the infusion of Making into the humanities (and vice versa) have staked out a field of inquiry and innovation they call "critical making":

Critical making signals the ways in which productions — whether of video, web-based communications, gardens, radio transmitters, or robots—are understood as politically transformative activities... Critical making invites reflection on the relationship of the maker to the thing produced, reflection on how elements (whether nuts and bolts, bits, and bytes, or breath, blood, flesh, brain, and neurons) work together-in short, consideration

as "patron saint," Blake also seems to serve as informal mascot for Make, a Romantic-era sage floating among articles about how to build your own robot with an Arduino or a Raspberry Pi.

${ }^{3}$ Roger Whitson and Jason Whittaker, William Blake and the Digital Humanities (New York; London: Routledge, 2013), 4. 
and awareness of the mediated and direct experiences of interacting with the material world. $^{4}$

One of the more visible products of this movement is Garnet Hertz's "handmade book" project, Critical Making, a "zine-like" series of ten volumes containing artists' and academics' responses to the Maker movement and their reflections on their own critical processes. ${ }^{5}$ More recently, a panel on critical making organized by Roger Whitson at the 2014 Modern Language Association convention offered myriad examples of scholars performing acts of critical making in collaboration with students and with researchers in non-humanities fields. ${ }^{6}$

In this essay I analyze current popular narratives of the Maker movement and its increasingly insistent rhetorical positioning as primarily a workshop for corporate commercial gain. I pay particular attention to the gendered aspects of this positioning to demonstrate how the Maker movement, despite claims to embrace craft and domestic activities like sewing, gardening, and cooking, obscures and even denigrates the care work that stands behind and enables Making — care work most often performed by women. I then apply this insight to a discussion of Catherine Blake, who has been the subject of a number of recent articles and books that attempt to bring her out of her husband's shadow, either by uncovering new documentary evidence of her contributions to William's art or by imaginatively constructing her now-irretrievable inner life by means of fictional

\footnotetext{
${ }^{4}$ Matt Ratto and Megan Boler, "Introduction," in DIY Citizenship: Critical Making and Social Media, ed. Matt Ratto and Megan Boler (Cambridge, MA: MIT Press, 2014), 2-3.

${ }^{5}$ Critical Making was published in an edition of 300 copies and "given away for free to project contributors, individuals and institutions important to them." See http://www.conceptlab.com/criticalmaking/. Included in each packet of ten booklets was a vinyl sticker featuring a cover image for Made magazine, a parody of Make. It satirized the "revolutionary" rhetoric of the popular Maker movement ("Join the Arduino Revolution but Avoid Civil Disobedience") and its lack of diversity ("101 DIY Gadgets for White Males"). A PDF of the sticker can be viewed at http://conceptlab.com/criticalmaking/PDFs/CriticalMaking2012Hertz-EnvelopeHertz-Made-VinylSticker.pdf ${ }^{6}$ See http://www.rogerwhitson.net/?p=2026.
} 
treatments. Rather than emphasize the work of "the lovely Catherine" at the press, thereby rhetorically transforming her into a "Maker," I consider the care work she performed, the difficulty of uncovering and representing this work within current academic frameworks, and the ways scholars of Blake and his art might treat her contributions both accurately and generously. I advocate a model of scholarship that might regard "William Blake" (both the historical man and the ongoing artistic and commercial entity) as an ecology—one in which Catherine's "care work" holds an important place that cannot be measured simply by counting how many works she colored or sent through the press.

I conclude the essay by examining the digital humanities' claim to embrace "critical making," arguing that the most "critical" part of the DH endeavor is the imperative to push against the erasure of non-material contributions like service, support, and care and to resist the obsession with materiality and the salable product that the popular Maker movement increasingly celebrates. The "timeworn polarity" discussed in the introduction to this cluster- the false dichotomy between those who think and those who make-is rivaled in its stubborn persistence perhaps only by the gendered polarity between those who make and those who care. All making is supported by care work and invisible labor, so to be truly critical, critical making must make critically visible the invisible labor that supports it. This is one way that digital humanists might counter the commercial Maker movement's “techno-fetishism," which “engag[es] with reprogramming products and technologies" only to "reproduce the same cultural scripts." The digital humanities should live up to the "humanities" part of their name by highlighting the human aspects of making, which are the most difficult to unearth and describe and those most likely to be ignored, forgotten, or glossed over

\footnotetext{
7 "Natalie Jeremijenko: Interview by Garnet Hertz," Critical Making: Conversations, ed. Garnet Hertz (Hollywood, CA: Telharmonium Press, 2012), 13. http:/ / conceptlab.com/criticalmaking/PDFs/CriticalMaking2012Hertz-Conversations-pp11 to16Hertz-JeremijenkoInterview.pdf
} 
by the fields (engineering, design) whose work is most evident in the finished product. In an effort to model this recommendation, I discuss Catherine Blake's presence in the William Blake Archive and the types of care work involved in the creation and maintenance of the Archive, which I managed for almost seven years. Considering Catherine's role in the making of Blake's art alongside the role of care work in a digital humanities project about Blake offers a method for thinking through the importance of invisible labor to the forms of "critical making" digital humanists claim to embrace.

\section{Selling the Maker Movement}

In the years since Make Magazine and Maker Faires launched in 2005 and 2006, respectively, the celebratory spirit of freedom and independent creation that Branwyn extolled in his canonization of Blake-as-Maker has been accompanied by increasingly strident insistence on the Maker movement's commercial potential. The current Maker movement is the most recent manifestation in a long line of home-based hobby activities that includes everything from zine publishing to model airplanes to motorcycle building, the farming and canning movements that arose in response to World War II rationing, and the samplers and home sewing of the eighteenth and nineteenth centuries. But while earlier artisanal movements like DIY and zine culture offered "potential antidotes to the excesses and apathies associated with consumer capitalism" and were thus particularly attractive to radical political collectives, the early-twenty-first-century Maker movement trends increasingly toward "depoliticized lifestyle and self-managerial branding." ${ }^{8}$ Commentators predict that the Maker movement will bring about a "new industrial revolution" that will return America to its rightful place in international trade, reversing the economic trends of the last several

\footnotetext{
${ }^{8}$ Red Chidgey, "Developing Communities of Resistance? Maker Pedagogies, Do-It-Yourself Feminism, and DIY Citizenship," in DIY Citizenship: Critical Making and Social Media, ed. Matt Ratto and Megan Boler (Cambridge, MA: MIT Press, 2014): 104, 107.
} 
decades that have made South and East Asian countries powerhouses of manufacturing while American productivity has languished. ${ }^{9}$ For this new movement, the alternative to "passive consumption" is marketable production; to escape the "enslavement" of one system is to be free to enrich another.

In this new incarnation the commercial Maker movement has less to do with the pleasures of creation and collaboration than with the possibility of gain. Dale Dougherty, often credited as the "founder" of the Maker movement, was not the first person to build something in his garage; instead, he assembled a communication and presentation network that enabled those interested in various forms of home-based craftsmanship to meet with, read about, and talk to one another. ${ }^{10}$ Dougherty, in other words, found a way to monetize a movement that was already under way and that harkens back to mid-twentieth-century publications like Popular Mechanics but also has roots in the "DIY music" scene of the 1970s (with its zines and small-batch vinyl presses), the garage PC building of Steve Jobs and Bill Gates, and the development of the internet and the World Wide Web in academic labs. ${ }^{11}$ Whereas the DIY movement has sometimes operated as "a leveller of class" or "a political force... facilitating the wider dissemination of subcultural views," the launch of Dougherty's Maker Faires was greeted by corporations like HP and Cognizant, who agreed to cosponsor the New York Maker Faire in September 2011. ${ }^{12}$ An article in The Economist from later that year pointed out that large corporations were buying up websites like Instructables (which allows

\footnotetext{
${ }^{9}$ There is a subset of the current Maker movement that resists the DIY and Maker movements' implicit emphasis on individual craftsmanship. Proponents of the Do-It-Together movement emphasize collaborative creation. But often even these discussions seem guided largely by economic principles such as cost-sharing.

${ }^{10}$ That network is corporatized in O'Reilly Media, which Dougherty co-founded and which publishes Make Magazine and sponsors Maker Faires around the U.S. and the world.

${ }^{11}$ Chris Anderson, Makers: The New Industrial Revolution (New York: Crown Business, 2012), 13.

${ }^{12}$ Atkinson, Paul Atkinson, "Do It Yourself: Democracy and Design," Journal of Design History 19 (2006), 1.
} 
users to distribute DIY designs and instructions) and that venture capitalists were investing in small maker-oriented companies like Quirky and MakerBot. ${ }^{13}$

As with early journalistic accounts of the internet in the 1990s, the assumption that Making is or should be primarily about making money is present in almost all recent popular discussions of the movement. While Makers themselves no doubt value the creative freedom and sense of accomplishment afforded by their efforts, popular commentators position these intangible benefits (when they mention them at all) as by-products of Making's economic potential rather than worthy goals in and of themselves: “[i]nventing something isn't enough,” one writes, "you've got to get it to market too, ideally in quantity." 14 Art and commerce-creation and monetization-need not be at odds with one another, as William Blake's own artistic career demonstrates, but in the rhetoric of the new Maker economy, made items that do not have an immediate market potential—ars gratia artis_are of particularly dubious value. Even commentators expressing concern for the future of the arts reduce artistic production to starkly economic terms: "you can go to your computer or smartphone and download... an app that will allow you to take a photo of something and then turn that photo into a digital file that you can print out with a 3-D printer. So, for example, you could make your own copy of some sculptor's work that you see in a local art studio window. Is that fair? Is that economically just?" ${ }^{\prime 15}$ Art, juissance, and pleasure are victims in this new economic model, not integral parts of it.

One of the hallmarks of popular writing on the Maker movement is its tendency to invoke the industrial revolution, usually as part of a decontextualized claim that altered patterns of design and production mark the beginning of an entirely new economic regime. The rise of Maker Faires,

\footnotetext{
13 "More Than Just Digital Quilting," The Economist, December 3, 2011.

${ }^{14}$ Chris Anderson, "20 Years of Wired: Maker Movement," Wired, May 2, 2013.

${ }^{15}$ John Tierney, “The Dilemmas of Maker Culture," The Atlantic, April 20, 2015.
} 
for instance, has prompted predictions of a national economic model in which more manufacturing is handled by small firms or even by individuals. "It is easy to laugh at the idea that hobbyists with 3D printers will change the world," one journalist writes. "But the original industrial revolution grew out of piecework done at home, and look what became of the clunky computers of the 1970s" ("More Than Just"). Anderson’s 2012 book Makers: The New Industrial Revolution describes the rise of the nineteenth-century textile industry in Manchester, England, as a boon to everyone born into race and gender privilege_- "between 1800 and today, life expectancy for white males in the West doubled"-while ignoring the enslaved Africans who grew much of the cotton used in Manchester and glossing over the unsafe and underpaid employment conditions of women and children in factories (37). ${ }^{16}$ Like Branwyn, Anderson invokes Blake, but rather than celebrate him as Maker, Anderson takes exception to the poet's depiction of England's "dark satanic mills," asserting by way of refutation that "the main effect of industrialization was to improve health" (36).

In these popular discussions of the Maker movement, garage tinkerers and maker labs act as inexpensive research and development arms for major corporations: "Makers can play in niches that big firms ignore-though they [i.e., big firms] are watching the maker movement and will borrow ideas from it" ("More Than Just"). These formulations embrace an Uber or AirBnB model of business development: corporations outsource risk, initial outlay, and personnel costs to individual "Makers," who create products that may or may not recoup their costs but whose success or failure will be judged solely in financial terms. (Not coincidentally, this is the same model increasingly followed by the corporate university: doctoral students finance their education through debt or poorly-paid teaching jobs on the ever-dwindling chance that they will find permanent employment in the academy at the end of their apprenticeship period.) The frequent claim among commentators

\footnotetext{
${ }^{16}$ At one point Anderson notes that "like it or not," many of the workers in factories and cottage industries were children. One wonders who among Anderson's readers likes child labor.
} 
that maker culture is "transforming" the American economy is thus true (if it is) only in a narrow, presentist sense, since the pattern of converting individual, home-based artisanship into mass production and distributing capital upward from labor to management has been entrenched since Blake's time; the twenty-first-century version simply overlays the neoliberal celebration of privatization and precarious labor. What popular extolments of Maker culture generally offer is a particularly uncritical approach to making: one in which the making of things on the small scale is a stepping stone to the making of money on a large scale and the patterns of the past are thoughtlessly repeated in the marketplaces of the future.

A movement so invested in monetizing creative leisure necessarily enfolds a number of gendered assumptions about which kinds of Making are valuable and which are not. As engineering professor Debbie Chachra notes, "The cultural primacy of making, especially in tech culture... is informed by the gendered history of who made things, and in particular, who made things that were shared with the world, not merely for hearth and home."17 As with their gestures to the joy of creating something with one's own hands, popular commentators frequently pay lip service to kinds of Making that do not involve technology or the potential for mass production- those traditionally associated with women. ${ }^{18}$ "It's not just about workshops, garages, and man caves," Anderson writes. "If you love to cook, you're a kitchen Maker and your stove is your workbench.... If you love to plant, you're a garden Maker. Knitting and sewing, scrapbooking, beading, and cross-stitching-all Making” (Makers 13). And yet even while acknowledging these domestic forms of Making, popular

\footnotetext{
${ }^{17}$ Debbie Chachra, "Why I Am Not a Maker," The Atlantic, January 23, 2015.

${ }^{18}$ The design historian Clive Edwards notes that "the eighteenth century saw the beginning of a decline in home-based economic production and much work that was done for the home had little commercial value.... In the fields of 'art and crafts', [the separation of the spheres of home and market] led to the distinction between amateur women and professional men, and more especially, the equating of specific crafts to 'women's work."' Edwards, "Home Is Where the Art Is: Women, Handicrafts and Home Improvements 1750-1900,” Journal of Design History 19.1 (2006): 12.
} 
commentators maintain the gendered hierarchy between productive, marketable, male-associated labor and reproductive, amateur, female-associated labor. Branwyn praised Blake for ostensibly resisting the repetitive labor of engraving and job-printing: "Unlike traditional engraving, which was largely a copyist medium, a means of reproduction, illuminated printing was a means of original production where you could compose your ideas, and paint them, right on the printing plate." ${ }^{19}$ The Maker movement can "sound a lot like the digital equivalent of quilting bees," The Economist admits before assuring the reader that it "has already had a wider impact" ("More Than Just"). Quilting, a traditionally female activity, must be transformed into mass-marketable products with "a wider impact," presumably by male industrialists. Anderson's account of the men who initiated the first industrial revolution ingenuously ignores the gendered history of the "spinning jenny" that begins his tale of economic transformation (Makers 33). ${ }^{20}$

The consequences of the Maker movement's gendered assumptions are not only rhetorical: the celebration of the presumptively male activity of Making actively denigrates and devalues activities essential to Making but not evidenced in the final product. Behind every made thing is "an invisible infrastructure of labor-primarily caregiving, in its various aspects — that is mostly performed by women" (Chachra). Sociologists and economic theorists call this often invisible labor "care work"; ${ }^{21}$ it includes those fields of endeavor, paid and unpaid, that contribute to the health and maintenance of society: child and elder care, education, and physical and mental health work. But

${ }^{19}$ This, of course, is an oversimplification, since in art "systems of production [are] in some sense almost always systems of reproduction." Morris Eaves, "Blake and the Artistic Machine: An Essay in Decorum and Technology," Publications of the Modern Language Association of America (1977): 903.

${ }^{20}$ As Roger Whitson has discussed, the "women's work" of weaving also influenced the early history of computing: Charles Babbage based his original design for the difference engine on the punch card system used by the Jacquard loom, while Ada Lovelace, the engine's first programmer, imagined it weaving "algebraical patterns" just as the loom wove designs. Whitson, "Critical Making in the Digital Humanities," in Introducing Criticism in the Twenty-First Century, Second Edition, ed. Julian Wolfreys (Edinburgh: Edinburgh UP, 2015), 157-76.

${ }^{21}$ Paula England, "Emerging Theories of Care Work," Annual Review of Sociology (2005): 381. 
the term can be applied to any type of labor that prioritizes the nurturing and management of workers over the invention and production of material things. ${ }^{22}$ It is notoriously undercompensated and disproportionately performed by women, while forms of labor that produce physical objects or multiply capital are more likely to be performed by men.

Care work is one of the most difficult—if not the most difficult—-things to acknowledge and reconstruct when examining the process of "making" because it is unlikely to leave physical evidence behind. Because its presence and influence are difficult to discern, its essentiality can be ignored or even denied. The commercial Maker movement, with its emphasis on the object produced and the capital that might be generated by the sale of that object, works toward the obscuration of care work. The William Blake embraced by the commercial Maker movement has thus been symbolically drafted — and "the lovely Catherine" with him—into the ranks of a "new Industrial Revolution" that elevates ostensibly masculine, productive, marketable virtues over female, reproductive, unmarketable ones.

\section{The Care Work of Catherine Blake}

Because scholars generally lack both research methodologies and a critical vocabulary for discovering and discussing the contributions of care workers to artistic and intellectual production, Catherine Blake's exact role in William Blake's work has been extremely difficult to excavate and reconstruct. Much of the current scholarship surrounding Catherine's role in her husband's life centers precisely on whether and to what extent Catherine herself was a "maker." Scholars seek to

\footnotetext{
${ }^{22}$ As Sarah Blackwood has convincingly argued, much academic labor, particularly editing, falls under the heading of "care work." See Blackwood, "Editing As Carework: The Gendered Labor of Public Intellectuals," Avidly, June 6, 2014. Lauren Klein has recently questioned how care work infuses the digital humanities, both in the materials scholars study and in the practices they employ. Klein, "The Carework and Codework of the Digital Humanities," blog post, http://lklein.com/2015/06/the-carework-and-codework-of-the-digital-humanities/.
} 
determine how many of the works attributed to William (or to printers using his plates after he died) were actually made by Catherine, or, perhaps less controversially, what portion of the creative and physical labor that went into making an illuminated book (etching the plate, inking the plate, operating the press, finishing the design with pen or washes after printing) was actually performed by Catherine. ${ }^{23}$ At the other end of the spectrum, some scholars as well as authors of fiction have sought to discover or at least imagine those aspects of Catherine's life not directly related to Blake's material production - to summon a Catherine who is more than a cog in William's creative process. Catherine thus provides an ideal historical case through which to examine the gendered dichotomy between making and caring as well as the way our scholarly discourses continue to elide the latter by elevating the former.

After close to two centuries of biography and scholarship that had little to say about Catherine, Joseph Viscomi's Blake and the Idea of the Book revealed the crucial role she played in the production of the illuminated books and others of Blake's works. Catherine, Viscomi asserted, served as William's “printer's devil”: William inked the copper plates and aligned them on the press bed; Catherine laid damp paper over them and turned the wheel to bring them through the rolling press, after which she hung the paper to dry. Catherine, in other words, was the "clean hands person," and this “division of labor" was highly efficient, allowing William to both accept commercial commissions and create original works of art without hiring a paid assistant. Plates and

\footnotetext{
${ }^{23}$ None of the critics engaged in this debate about Catherine Blake uses "making" in the terms with which the commercial Maker movement uses it, of course. Instead, these Blake scholars seek to know whether Catherine was an "artisan" or an "assistant." "Artisan" implies a combination of mechanical and design skill as well as masterful command of a process; "assistant" implies subordination but also a close physical relationship to the process of production. "Maker" could mean just about anything, and in fact tends to elide the human altogether-what matters is that something is made.
} 
paper entered the "press bed" together and were joined in "marriage," with William at one end of the press and Catherine at the other. ${ }^{24}$

Since the publication of Blake and the Idea of the Book, scholars have sought additional evidence of Catherine's material contributions to Blake's art. Attempts to pin down the exact nature of Catherine's artistic contributions rely on exhaustively researched documentary and material evidence, and yet scholars of William and Catherine's life together find themselves faced with the prospect that " 180 years since her death there is little hope of recovering the historical Catherine Blake." 25 Scholars do know, from William himself, that Catherine was an excellent intaglio printer: Blake wrote that his wife could print intaglio engravings "to admiration \& being under my own eye the prints are as fine as the French prints \& please every one."26 Recent endeavors to establish Catherine as an independent artisan go beyond Blake's assertions, however. Angus Whitehead's 2012 article "An Excellent Saleswoman: The Last Years of Catherine Blake" describes the Blakes' final months together and the short time that Catherine lived after her husband's death. According to Whitehead, the widowed Catherine, having received a small inheritance from her brother-in-law and sold one of William's paintings at a generous price, moved into an artist's studio and supported herself by printing and selling copies of her late husband's illuminated books. Whitehead claims that "Catherine was an artist and printer in her own right, with firsthand knowledge and experience of Blake's art practices" that served her well after his death. ${ }^{27}$ Joseph Viscomi's current work in progress examines the material evidence for Catherine's printing practices after Blake's death. More

\footnotetext{
${ }^{24}$ Joseph Viscomi, Blake and the Idea of the Book (Princeton, NJ: Princeton UP, 1993): 103-105, 117. ${ }^{25}$ Joel Gwynne and Angus Whitehead, "The Sexual Life of Catherine B.: Women Novelists, Blake Scholars and Contemporary Fabulations of Catherine Blake," in Sexy Blake, ed. Tristanne Connolly and Helen P Bruder (New York: Palgrave MacMillan, 2013): 194.

${ }^{26}$ William Blake to James Blake, 30 January 1803. Reprinted in Geoffrey Keynes, The Letters of William Blake (New York: The MacMillan Company, 1956): 82.

${ }^{27}$ Angus Whitehead, “An Excellent Saleswoman': The Last Years of Catherine Blake,” Blake/An Illustrated Quarterly 45.3 (2012): 76.
} 
interestingly for purposes of this essay, however, Viscomi argues for Catherine's care work (though without using this term), asserting that she was "remarkable in her own right," not only because of her material contributions to Blake's printing process but because she was "extraordinarily tolerant, loving, empathetic, and accepting, and [thus] participated in Blake's life and works in ways too deep and profound for most of us to understand."28

Such praise recalls a tradition stretching back at least to Mona Wilson’s 1928 biography of Blake; Wilson asserted that "No one can understand Blake's life without being aware of the significance of [Catherine's] helpful and faithful figure, nor is it possible to think of him with a different type of wife without loss, even without the utter destruction of the fabric of his life." 29 These assessments can seem patronizing to those who wish to argue for Catherine's essential material contributions to Blake's art-for Catherine as co-Maker. But they are only offensive if one assumes that tolerance, love, empathy, and acceptance are less important to the creative process than inking a copper plate or applying wash to a printed impression-that material contributions trump care. Certainly helpfulness and faithfulness are less likely to leave evidence behind in the form of embossments and plate marks; note that both Wilson and Viscomi remark on the difficulty of understanding the personal relations between William and Catherine. But it does not follow that because they have not been systematically recorded they were not crucial to the creation of a finished artistic product.

Lacking extensive material and documentary evidence of Catherine’s care work, many authors have turned to fiction, engaging in what Joel Gwynne and Angus Whitehead call "fabulations" of Catherine's experiences (193). ${ }^{30}$ In response to these fictionalizations—or perhaps

\footnotetext{
${ }^{28}$ Joseph Viscomi, email message to author, June 17, 2015.

${ }^{29}$ Mona Wilson, The Life of William Blake (London: The Nonesuch Press, 1927): 303.

${ }^{30}$ Gwynne and Whitehead discuss Barbara Lachman's Voices for Catherine Blake: A Gathering (2000); Janet Warner's Other Sorrows, Other Joys: The Marriage of Catherine Sophia Boucher and William Blake
} 
extrapolations_of Catherine, Mark Crosby and Angus Whitehead's "Georgian Superwoman or 'the Maddest of the Two'? Recovering the Historical Catherine Blake, 1761-1831" "attempt[s] to reclaim the historical Catherine, jettisoning the unreliable mythology and sentimental accretions of the nineteenth and twentieth centuries." ${ }^{31}$ Current Blake scholarship, then, is engaged in a struggle to address a question that the popular Maker movement chooses to ignore: how does one properly assess and credit the contributions of those whose work is primarily invisible and affective (and thus almost always unrecorded)? As of now, however, these attempts fall into largely binary patterns: Catherine is either artisan or helpmeet, either maker or carer.

These binaries are generated, both in the popular Maker movement and in the scholarly discourse on Blake, by the undeniable presence and materiality of the made object. The thing-thatis-made stands as both the object of study and the repository of all evidence regarding its own production, effacing with its solid thingness the ephemeralities — including the conditions of carethat made its production possible. To move beyond the binaries that characterize scholarship of care work in general and Catherine more particularly, it may be necessary to refocus our attention away

(2003); and Marsha Keith Schuchard's Why Mrs. Blake Cried: William Blake and the Sexual Basis of Spiritual Vision (2006). Another recent contribution to the genre is David Park's The Poets' Wives (2014).

${ }^{31}$ Mark Crosby and Angus Whitehead, "Georgian Superwoman or 'the Maddest of the Two'? Recovering the Historical Catherine Blake, 1761-1831," in Re-envisioning Blake, ed. Mark Christopher Crosby, Troy Patenaude and Angus Whitehead (Houndmills, Baskingstoke, Hampshire; New York: Palgrave Macmillan, 2012), 86. In the introduction to their edited collection Sexy Blake, Helen P. Bruder and Tristanne Connolly take issue with Crosby and Whitehead for "gleefully speculating about Catherine's physical attractiveness and willingness to be 'as sexually accommodating' as the Soho whores, and also freely assuming she'd have lamented her 'childless' state and happily posed as a nude model." They further question "the dubious-possibly ironic_-binary set-up in the title between heroic or nutty wife" as well as "the titular erasure of the 20 years Catherine spent as neither a wife nor a Blake." Bruder and Connolly, "Introduction: 'Bring Me My Arrows of Desire': Sexy Blake in the Twenty-First Century," in Sexy Blake, ed. Tristanne Connolly and Helen P. Bruder (New York: Palgrave MacMillan, 2013), 7. 
from the fixed point of the material object and toward the network of relations that brought it into being.

Recent work that figures "William Blake" as a collective entity moves in this direction by tracing the historical William Blake while also recognizing that the man and his art were inextricably interconnected with the people and things around him, most significantly Catherine. Crosby and Whitehead, for instance, refer to Catherine and William as the "firm" of "Wm Blake": "When Blake died, the 'firm' ceased operating," they claim, but from 1829, "through the efforts and improved material circumstances of Blake's widow, Catherine, 'Wm Blake' would continue to trade for another two and a half years" (106). But thinking of Blake as a "firm" has many of the same disadvantages as applying the Maker term: it positions artistic and material production as primarily money-making enterprises, and even encourages us to think of Blake as analogous to a modern-day CEO, a characterization he would likely have abhorred. Roger Whitson and Jason Whittaker offer another way of thinking about Blake as collective event: they 'imagine the entity 'William Blake' as an ontologically democratic network or society made up of everything from the ideas that inspired Blake to the material objects he used in his artwork, the animals and plants he ate, and the individuals who were influenced by his work" (13). While it can be useful to think of Blake and his surroundings as "ontologically democratic," this term runs the risk of obscuring or minimizing the very un-democratic political realities that characterized William and Catherine's lives, including the gender and sexual norms that would have prevented Catherine from becoming a professionally trained "artisan in her own right," had she wished to do so.

We might instead find it helpful to think of Blake and his surroundings as an "ecology," since an ecosystem includes entities that are interdependent but also exist according to complex power relations: predator and prey, parasite and host, symbiote and symbiote. In the Blakean "ecology," Catherine can exist in multiple positions relative to William: his apprentice in printing, his 
superior in home economy, ${ }^{32}$ perhaps even his master, by George Cumberland's account, in

"madness." 33 She can be simultaneously an expert intaglio printer (the rival of the French), a "devil"

pulling illuminated works through the press, a painter who gifted her creations to Mrs. Thomas

Butts ${ }^{34}$ the household manager placing food on the table, and a host of others not recorded but

nevertheless essential. These positionalities may be more or less difficult for scholars to discover and

reconstruct using the evidence and tools available, just as the activities of birds in a tropical

rainforest are easier to measure than those of insects. But just as ecosystems do not function

without the difficult-to-discern activities of insects, there is no "William Blake" as we know him-

historical figure or atemporal creative entity—-without Catherine. ${ }^{35}$

${ }^{32}$ Blake's early biographer Alexander Gilchrist noted Catherine's canny way of communicating with her husband about their financial circumstances:

It put him out very much when Mrs. Blake referred to the financial topic, or found herself constrained to announce, 'The money is going, Mr. Blake.' 'Oh, d--- the money!' he would shout; 'it's always the money!' Her method of hinting at the odious subject became, in consequence, a very quiet and expressive one. She would set before him at dinner just what there was in the house, without any comment until, finally, the empty platter had to make its appearance: which hard fact reminded him it was time to go to his engraving for a while." Alexander Gilchrist, Life of William Blake with Selections from his Poems and Other Writings (New York: Phaeton Press, 1969): 356.

${ }^{33}$ George Cumberland, Sr., wrote to his son in 1815 that Blake was "a little Cracked, but very honest - as to his wife she is the maddest of the Two." Quoted in G.E. Bentley, Blake Records, second ed. (New Haven and London: Yale University Press, 2004), 321.

${ }^{34}$ See Crosby and Whitehead, 100.

${ }^{35}$ My use of the word "ecology" may call to mind current work in ecocriticism and the environmental humanities. But whereas these fields "seek to understand... how particular texts represent the interactions between humans and their ecological environment [and] how such representations reflect and shape real-world environmental practices," I am concerned with the Blakes (and with "Blake" as a scholarly object) as an ecology in and for themselves, their collaborators, patrons, and readers. My use of this term is thus more metaphorical than biological. Hannes Bergthaller, "Introduction: Ecocriticism and Environmental History," Interdisciplinary Studies in Literature and Environment 22 (2015), 6. I also obviously owe something to Deleuze and Guattari's concept of the rhizomatic book, though my model of a Blakean ecology does not embrace that term's radical multiplicity. Rather than "[s]ubtract the unique from the multiplicity to be constituted," I suggest instead that scholars of Blake interrogate the conflation of uniqueness and individuality. In what ways does Catherine constitute an indivisible aspect of Blake's uniqueness? In what ways were they uniquely one? Gilles Deleuze and Felix Guattari, A Thousand Plateaus: Capitalism 
Rather than reducing Blake to the objects he produced, in a Blakean ecosystem—and, by extension, in a larger Romantic one-the made object becomes less the end product of a series of defined steps than evidence of the recursive processes at work in that system. Rather than drawing a hard line between "production" and "reproduction" or between artistic labor and care work, the scholar of Blakean ecology seeks to describe the constellation of conditions that accounts for the germination, generation, and dissemination of the words, ideas, and objects known as "Blake's." Thinking of Blake as an "ecology" is useful because it is an additive construction rather than a subtractive one: accounting for Catherine's contributions to the Blakean ecology need not diminish William's. It also helps forestall the temptation to individualize Catherine on little evidence by grafting facts gleaned from material objects onto her and then arguing, perhaps inaccurately, that she performed more of the material labor of artistic production than she likely did. In a Blakean ecology, care work is acknowledged as necessary to the production of material objects and therefore essential to an account of their creation. Catherine's care is part of William's craft, and vice versa.

\section{Traces of Care: Catherine Blake in the William Blake Archive}

Approaching "Blake" as an ecology offers a conceptual method for applying the principle of "critical making" to studies of Blake. This method links "the act of making 'things" that scholars of Blake so assiduously study to the "critically infused reflection about aspects of the process itself" that critical makers embrace (Ratto and Boler 2-3). Highlighting Catherine's role in the Blakean ecology helps to illuminate the importance of care work and invisible labor to processes of making - an intervention much needed in both the popular Maker movement and the digital humanities. As noted in the introduction to this article cluster, Blake has been the subject of a

and Schirophrenia, trans. Brian Massumi (Minneapolis, London: University of Minnesota Press, 1987), 6. 
number of digital humanities projects stretching back to the earliest decades of humanities computing. As one these projects—and the longest continuously publishing one- the William Blake Archive could model a more critical digital humanities by finding ways to reveal and credit Catherine's role in the creation of those works known as Blake's.

Though Catherine by all accounts performed functions essential to the material production of Blake's art, it can still be difficult to find evidence of her in the William Blake Archive. This is in part a function of the Archive's own concern with the materiality of Blake's work. The fundamental unit of the Archive's digital editions is not the line, stanza, or poem or even the copy, edition, or work, but the object: the physical sheet of paper with something on it that was written, drawn, or printed by William Blake's hands. This emphasis on the physical object is reflected in the Archive's data model and its naming conventions and has the effect, in practice, of minimizing everyone who is not the historical William Blake. ${ }^{36}$

Nevertheless, Catherine's contributions are dotted throughout the Archive. Because, as discussed above, she likely operated the press during the printing of many of Blake's illuminated books, she appears with the designation "printer" on the Copy Information pages for illuminated

\footnotetext{
${ }^{36}$ All images of Blakean objects are given filenames that reflect the medium of the original object: WC for watercolor, PID for pen and ink drawing, MS for manuscript, etc. Any object not created by Blake is given an RM designation, for "Related Materials," regardless of medium. (None of these objects have been published in the Archive yet, so as of now these filename designations are for internal tracking purposes only, but they reflect the priorities and organization of the Archive and are codified in the Archive's table of contents at http://www.blakearchive.org/blake/indexworks.htm.) The "RM" category includes, among other things, drawings by Blake's brother Robert, portraits of Blake, and marginal inscriptions written by Cumberland on some of Blake's watercolors_-items of interest to scholars that are nevertheless not by William Blake. The use of the "RM" designator segregates these items, in the Archive's code, from those produced by Blake. As of this writing there is only one item in the "RM" category that pertains to Catherine: George Cumberland's pen and ink drawing of her reading a newspaper or large broadside (c. 1783-5). (See Blake/ An Illustrated Quarterly, volume 39, issue 4 (Spring 2006) for more information and an image of the drawing: http://bq.blakearchive.org/39.4.essick\#p163.)
} 
book editions. ${ }^{37}$ Since it is difficult to pinpoint exactly which books she printed (though future scholars may be able to do so using the high-resolution images available in the Archive), this designation has been included in each copy of each illuminated book to indicate the likely possibility that she was involved in their printing. This practice may overstate Catherine's involvement in the printing process — it is difficult to know whether she operated the press for every copy of every illuminated book—but it acknowledges her ongoing contributions to the making of William's art. For a few illuminated books Catherine is also credited as "colorist," 38 though this designation does not appear as often because material and documentary evidence for her coloring is more difficult to verify. She is prominently featured on the Work Index page ${ }^{39}$ for the engraved illustrations to William Hayley's Life of Comper, for which she may have printed as many as 2000 impressions. ${ }^{40}$ (Strangely, the Work Index page for Little Tom the Sailor, which Catherine also printed, does not mention her, though she is designated on each Copy Information page as "printer.") She receives two mentions in Joseph Viscomi’s “Tlluminated Printing" article, as "Mrs. Blake." ${ }^{41}$ And her name appears throughout the Archive in provenance notes as the inheritor of Blake's unsold works after his death.

There are, however, many ways that Catherine's contributions to the Blakean ecology could be recognized more explicitly in the William Blake Archive, without running the risk of "fabulation."

\footnotetext{
${ }^{37}$ See, for instance, the Copy Information page for Songs of Innocence copy B: http://www.blakearchive.org/exist/blake/archive/copyinfo.xq?copyid=s-inn.b.

${ }^{38}$ See, for example, the Copy Information page for Europe a Prophecy copy A: http://www.blakearchive.org/exist/blake/archive/copyinfo.xq?copyid=europe.a. ${ }^{39}$ Available here: http://www.blakearchive.org/exist/blake/archive/work.xq?workid=bb468\&java=no. 40 "The epistolary and material evidence indicates that Catherine was responsible for printing the four quarto-sized, intaglio plates for the first two volumes of Hayley's Life of Cowper (1803-4). The print-run for the first 1803 edition of Hayley's biography of Cowper was approximately five hundred copies, which indicates that Catherine printed approximately two thousand impressions" (Crosby and Whitehead 98).

${ }^{41}$ http://www.blakearchive.org/exist/blake/archive/biography.xq?b=illum\&targ_div=d1
} 
Some of these changes are technical, while others would involve the addition or alteration of content. Most significantly, an improved search feature would allow users of the Archive to more easily access Catherine's contributions. The current search feature, launched in 2011, allows users to search some, but not all, of the scholarly apparatus that accompanies the Archive's digital editions. A search through editors' notes and Work/Copy Information pages for mentions of Catherine returns 41 results, but the quirks of the search code are such that these results do not include the "printer" and "colorist" designations on Copy and Work Information pages (noted above). Providing a more accurate and thorough search feature would help users seeking information about Catherine to retrieve all mentions of her in the Archive and thus to form a clearer picture of her role in Blake's production process.

But the William Blake Archive includes more than digital editions, and it is in the other sections of the site that Catherine's role in the Blakean ecology could be more thoroughly acknowledged. The site's biography of William includes few mentions of Catherine, either as care worker or as printing assistant. The same is true of the chronology that appears alongside the biography in the site's "About Blake" section. The Archive could improve its treatment of Catherine Blake by either revising the site's existing biography or by commissioning a separate biography of Catherine. Such a change would improve the accuracy of the site's current contextual materials. Since "[f]or almost forty-five years she was the person who lived and worked most closely with Blake, enabling him to realize numerous projects, impossible without her assistance," biographies that largely ignore her presence paint an incomplete picture of her own and William's life and work (Whitehead 76).

Of course, we can never be certain exactly what Catherine brought to the Blakean ecology because Catherine herself left almost no trace of her existence (just an " $\mathrm{X}$ " in the marriage register and a few inscriptions to friends). Because the experience of care is deeply personal, a lack of first- 
hand evidence makes reconstructing care work a difficult and fraught enterprise_-one that is sometimes only achievable through imaginative forms like the recent fictional and poetic works that imagine Catherine's life. It is for this reason that digital humanists, including those who work on projects like the William Blake Archive, should be particularly intentional about recording their own care work. If we wish to understand the invisible labor and affective commitments that make digital humanities projects possible, then those who build and maintain $\mathrm{DH}$ projects must be encouraged to speak for themselves about all aspects of their work, not just the code or material artifacts they produce. Roger Whitson and Jason Whittaker have called for "a Blakean account of labor in the digital humanities," one that

lies in refusing older industrial critiques of mechanized labor, in which the human and the organic are seen as ontologically prior to the machine and the tool. Blakean digital humanities must embrace... a networked understanding of creativity that includes humans, animals, insects, plants, and machines....” (171)

If digital humanists are to resist the corporatizing and falsely gendered impulses of the commercial Maker movement and create a truly critical digital humanities, then our "networked understanding" of our work must make explicit all of the forms of labor-including care work-that make the digital humanities possible.

I have written elsewhere about my own "behind-the-scenes" labor as Project Manager of the William Blake Archive, ${ }^{42}$ but that article said little about the care work I performed in that role. Foregrounding the care work of the digital humanities requires us to bring up uncomfortable questions of affect—questions that generally do not get discussed in academic publications because to mention them is to risk being labeled "unprofessional." Addressing them fully requires us to drop

\footnotetext{
${ }^{42}$ Ashley Reed, "Managing an Established Digital Humanities Project: Principles and Practices from the Twentieth Year of the William Blake Archive," Digital Humanities Quarterly 8.1 (2014).
} 
the curtain of professional disinterestedness, if only for a short time. Personally, I can assert that I care very deeply about the Blake Archive and its staff, and that in addition to the pecuniary and professional rewards of my involvement, my personal feelings about the project have been a major factor in my decision to devote so much time and energy to it over the years. Holding a colleague's infant daughter on my lap while I prepared XML documents for publication; hearing our former Technical Editor and his girlfriend, one of our graduate assistants, announce their engagement; winding down at a bar with assistants after the last night of our annual (and exhausting) Blake Camp marathon meeting; and consulting the editors about how we could best support staff members with ongoing health problems — these affective and personal experiences, I venture to state, have contributed nearly as much to the continued productivity of the Archive and my ongoing commitment to it as the hours spent transcribing texts or marking up illustrations. And they can be understood only within the ecology of the William Blake Archive, in which the professional relationships between editors, project managers, and staff reflect our personal commitments to the project and to one another.

This kind of care work is difficult to describe and even harder to quantify, but if digital humanists wish to properly assess and value how care work contributes to our field, we must find ways to properly credit that work within the incentive structures of the academy, which continue to certify some forms of labor as more worthy of acknowledgment and reward than others. Within the academy, care work faces the same predicament of undercompensation it does in the larger economy: care work is classified as non-productive_-as service_-and is less valued and rewarded than the supposedly more productive labor of creating original scholarship. These divisions ignore the fact that all scholarship depends on service, including a whole host of librarians, departmental staff, peer reviewers, systems administrators, and others whose labor is largely ignored except for the occasional aside in a book or article’s acknowledgments. Willard McCarty recently recommended 
that scholars "rid digital humanities permanently of the class distinction between technician servant and academic master. Let us look closely at what this class distinction has done to both master and servant." ${ }^{43}$ The scholarly economy suffers from the same myopia as the commercial Maker movement: a fixation with the final product and the pecuniary and reputational rewards it promises and an attendant inattention to forms of labor not immediately in evidence there. The false binary between Catherine's care and William's labor is perfectly preserved, even in the supposedly paradigm-changing field of $\mathrm{DH}$. To create a truly critical digital humanities we should acknowledge and foreground the interdependencies between different kinds of labor and recognize the ecologies of creativity that make both art and scholarship possible.

\footnotetext{
${ }^{43}$ Willard McCarty, "the end," email message to Humanist mailing list, August 10, 2015.
} 